\title{
The transformation of the organic energy system: the Swedish perspective
}

\author{
Magnus Lindmark ANd FredriK Olsson-SpJut
}

KEYWORDS: organic energy system, energy history, Sweden, firewood.

JEL CODES: N00, N53, N72, N73.

his article discusses the historical conversion of the Swedish organic energy sys-
tem into a mineral one. The main argument is that there was a dynamic in-
teraction between the two systems during the Swedish industrialization process. For one, growth of the mineral energy system contributed to open previously inaccessible organic resources in the forests of northern Sweden. Secondly, the development of the pulp and paper industry contributed to the switch from charcoal to coke in the iron manufacturing industry. Thirdly, the development of hydropower, itself an organic source of energy, further contributed to the emergence of a mixed energy system. One can therefore perceive the Swedish transition from an organic to a mineral energy system as a shift from a traditional organic energy system to an industrialized one, that is, an organic energy system dependent on the technologies and organizational structures of the mineral energy system in order to function. 


\section{La transformación del sistema de energía orgánica: la perspectiva sueca}

\section{PALABRAS CLAVE: sistema energético orgánico, historia de la ener- gía, Suecia, leña.}

\section{CÓDIGOS JEL: N00, N53, N72, N73.}

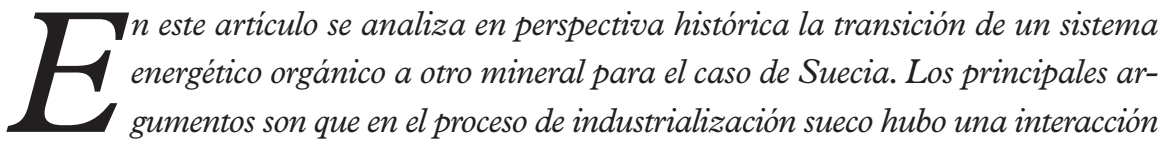
dinámica entre ambos sistemas. En primer lugar, observamos que la expansión del sistema energético mineral facilitó el acceso a recursos orgánicos en el norte de Suecia, antes inaccesibles. En segundo lugar, comprobamos que el auge de la industria papelera fue un factor clave en la transición de le industria del hierro desde el carbón vegetal al coque. En tercer lugar, el desarrollo de la energía hidráulica, una fuente de energía orgánica, contribuyó adicionalmente a la coexistencia de un sistema energético mixto. Planteamos, por tanto, que la transición de un sistema energético orgánico a uno mineral en Suecia puede entenderse como el cambio de un sistema de energía orgánica tradicional a otro también orgánico pero industrializado, esto es, a un sistema energético que para su funcionamiento era dependiente de tecnologías y estructuras organizativas del sistema mineral.

Magnus Lindmark [orcid.org/0000-0002-3293-2318] is Professor of Economic History at Umeå University (Sweden). Address: Department of Geography and Economic, Umeå University, 90187 Umeå (Sweden). E-mail:magnus.lindmark@umu.se

Fredrik Olsson-Spjut [orcid.org/0000-0002-7446-0873] is Senior Lecturer in Economic History at Umeå University (Sweden). Address: Department of Geography and Economic, Umeå University, 90187 Umeà (Sweden).E-mail:fredrik.olsson-spjut@umu.se 


\section{INTRODUCTION}

Already in the 1960's Tony Wrigley pointed out that the industrial revolution could be analyzed in terms of changes in the way society was organizing its energy flows (Wrigley, 1962). Prior to the industrial revolution, energy flows were based on photosynthesis, a system Wrigley labelled the organic economy. As the capacity to produce energy in the form of foodstuffs, fodder and firewood through photosynthesis was ultimately limited by the acreage available for forest and agriculture, the potential for achieving economic growth was limited in the organic economy, an argument that rests on the assumption that energy is complementary to man-made capital. Coal did not experience the same limitations on the size of the energy flows and therefore allowed economic growth. The emergence of modern, high and sustained economic growth rates were therefore closely associated with the succession from an organic to a mineral-based economy. More recent empirical work has analysed energy transitions in several countries based on quantitative estimates of the development of various forms of primary energy such as firewood, coal and oil. The works of Tony Wrigley (1988, 2010, 2016), Richard Wilkinson (1988), Peter Sieferle (2001), Kenneth Pomeranz (2000) and even Bob Allen (2009) aims at understanding the industrial revolution and they all, in different ways, recognize the role of energy in this transformation. Another line of research has aimed at reconstructing historical energy data in foremost physical units, elaborating measures such as the energy intensity of GDP (Gales et al., 2007; Kander, Malanima \& Warde, 2013; Lindmark \& Minde, 2018).

The ambition of this article is to present an analysis of the Swedish industrialization from an energy historical perspective, with the aim to uncover dynamic relationships between economic and energy transformation. Our main argument is that the Swedish industrialization process was shaped by the co-evolution of organic and mineral systems and these dynamics, in turn, were shaped by the industrialization process itself. We attempt to use a holistic view, deliberately avoiding to focus on the energy system itself, while arguing that the energy transition also interacted with institutional changes, entrepreneurial activity and technological change that affected demand for fuels and raw-materials through changing relative prices.

Early modern Sweden enjoyed vast per capita forest and hydropower resources which, however, could not be fully realized due to relatively poor agricultural conditions. Interestingly enough, the plentiful per capita forest and hydro resources mirrored a low population density. Due to its fair supply of firewood and hydropower, Sweden appears as a relatively blessed country during the pre-industrialized era as far as energy resources are concerned. With the exception of the southernmost parts of the country, forest was a dominant feature of the landscape. Inland Norrland, a significant part of the country's land 
area, was to an even higher degree dominated by woodlands. Yet, many of these resources were largely inaccessible for economic exploitation of any significant scale. The organic energy resources of a good part of the country's area were therefore not assets in an economic sense. As we try to argue in the article, this was a consequence of the organic energy system itself. The paradox is that the organic energy system limited the access to organic resources.

MAP 1

Area of research

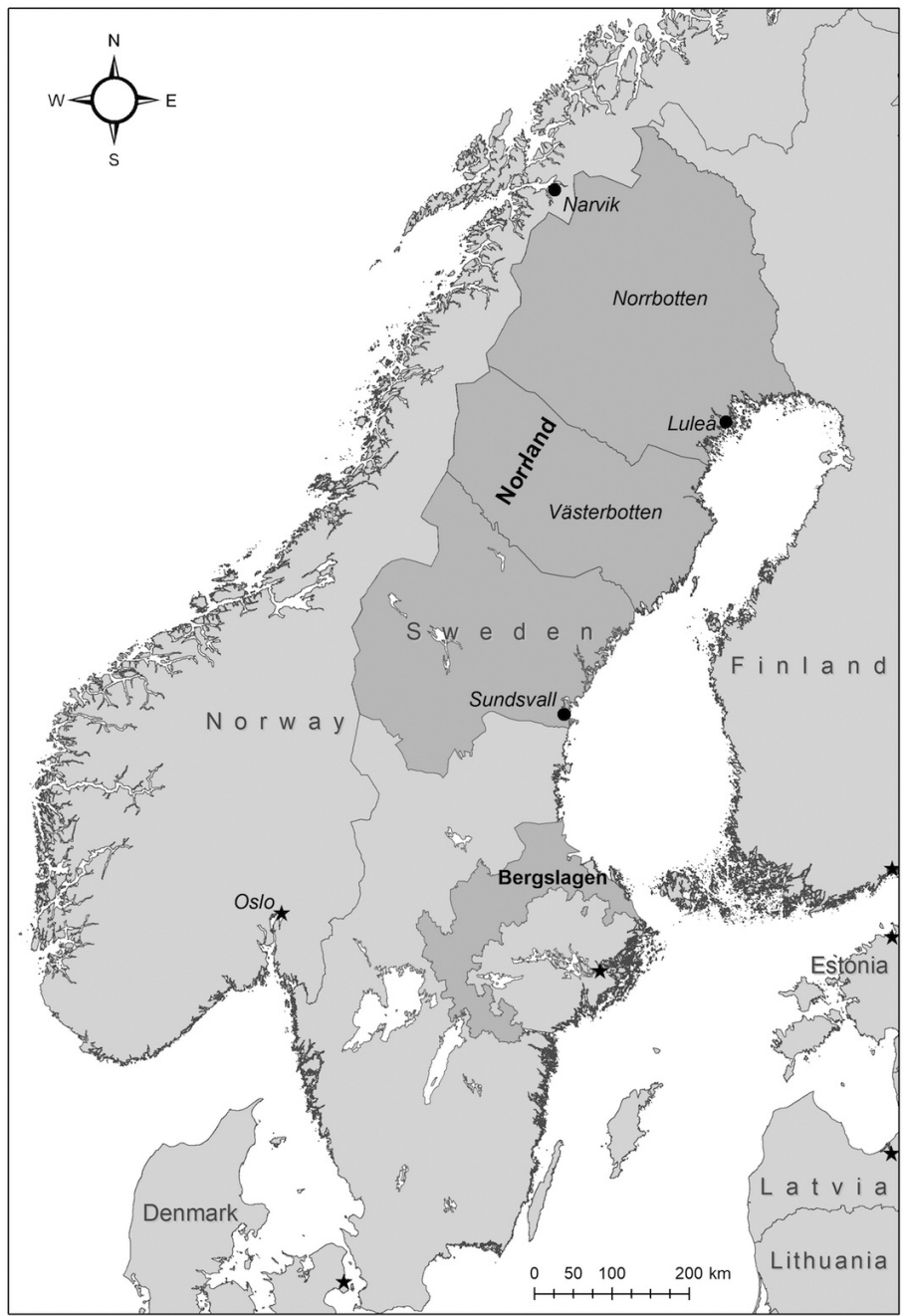


Around three quarters of the Swedish land area is found in the boreal coniferous forest, or taiga. A short growing season meant that the supply of productive agricultural land was limited in comparison to 3 European countries. The exception was the southern parts of Sweden, with agricultural conditions more similar to Denmark or Germany. We also notice evidence of agricultural surpluses in the Stockholm Mälardal region from the $17^{\text {th }}$ century (Myrdal, 1999). Generally, however, inadequate farming conditions, mainly determined by the country's northern location, explain the low population density compared to central Europe. The flip side of the low population density was, however, a large stock of non-agricultural assets in the form of forests and hydropower. Additionally, Sweden was endowed with significant mineral resources, with known deposits of iron and copper ores in the mid-central districts known as Bergslagen.

As the conditions for agriculture in these districts were not fully satisfactory, but since parts of the surpluses in the Mälardal region could be used for supporting miners and iron workers, there was enough manpower for the development of an iron and copper industry (Jonsson, 2001: 89-91) In short, the early modern iron industry benefited from a favorable factor endowment of mineral resources, hydropower, decent agricultural conditions and adjacent boreal forests for charcoaling. It was, however, difficult or even nearly impossible to utilize the resources of northern Sweden before the industrialization itself.

\section{NORTHERN SWEDEN AND ITS FACTORS OF PRODUCTION}

The fact that factor endowments frame the energy transition from an organic to a mineral energy was evident in the case northern Sweden. In this part of the country there were large areas of more or less unexploited forests, especially old-grown spruce with high-quality, dense timber which was due to the slow rate of growth in the harsh climate. When Carl von Linneus undertook his expedition to Lapland in 1732, he noted the economic potential of the forests, but also pointed out that the trees stood there, in vain and to no benefit. (Linnaeus, 1960). The timber did not have any commercial economic value. Linnaeus argued that if only the right spirit was there to cultivate the forest, there were enormous riches to be gained. While the continental powers fought over overseas colonies, Sweden had a colony within its own borders. The idea of an internal colonization was not at all new in the 1700s (Sörlin, 1988: 24). Sverker Sörlin points out that Olaus Magnus already in 1555 cited old authorities giving voice to the same idea. Northern Sweden had several small coastal towns that had been established in the Middle Ages, while the area was indeed populated before the Swedish Crown had put the coast under its jurisdiction. For long, historians have tried to understand who these first settler were, including speculation over the true identity of the mysterious Kvaener as well as the emergence of the 
Birkarlar in the $14^{\text {th }}$ century (Harrisson, 2002: 741-50). The latter may have been a then new word for the indigenous non-Sami population who earned their living in a combination of agriculture, fishing, hunting and trade, and who, after the area was put under the jurisdiction of the Swedish crown in the $14^{\text {th }}$ century, also came to function as state officials and tax collectors. Northern Sweden, not the least the interior parts, was also populated by the Sami people, with an economy based on reindeer nomadism, fishing, hunting and trade. The settlements in the interior were during the 1600 s very small, obviously a reflection of the harsh climate, most notably a short growing season with a persistent risk of crop failure. Basically, proper farms were found along the river valleys in the coastal area, while the inland favoured hunting. From a biological perspective, northern Swedish agriculture was highly dependent on dairy farming, since the short but intense growing season was relatively most favorable for grass (Gadd, 2000). The Sami reindeer herding utilized non-cultivated fodder, lichens, in areas were agriculture was practically impossible. The forest was used for domestic building material and fire wood, but not for commercial purposes of any important degree. An important factor explaining why the forests were not used for commercial purposes was the low population density and, therefore, an inadequate labor supply.

The existence of huge iron ore deposits in the northern parts of the country were known from $1642^{1}$ (Norberg, 1958). Regrettably, the majority of these deposits had a too high phosphorous content to be utilized with contemporary technology. Sufficiently large low-phosphorous deposits had, however, been discovered for advancing an industrial exploitation, a project which faced at least two major challenges. Firstly, the population in northern Lapland was even smaller than in other parts of Norrland and, secondly, the forest supply was limited at best. This meant that the ores of Norrland were inaccessible implying that the only remaining solution was to transport iron ores to the ironworks that had been established along the coast. The transport network, depending on rain deer sledge transports during the winter was, however, not successful, due to low economies of scale. It is furthermore important to recognize that the main reason for allocating iron works along the Norrland coast was to counteract the fuel shortages in the central Swedish iron districts. Due to the problems related to transportation and extraction, the ores for the Norrland ironworks were shipped from the Stockholm archipelago. The vision of a large-scale colonization of inland Norrland, exploiting forest and mineral resources, was however not possible until a sufficiently large population could be established. Basically, this could not happen before the interior Norrland was integrated in the growing national and international economy, something that only happened decades after the Industrial Revolution. Before we attempt a more holistic interpretation of the Swedish en-

1. Kengis iron works was granted privileges in 1643. 
ergy transition and industrialization, it is, however, necessary to look more closely into how the hallmark technology of the industrialization, the steam engine, diffused into Sweden, thereby significantly linking the Swedish economy to the mineral energy system.

\section{SWEDEN ON STEAM}

The Dannemora mine steam engine project of 1728 exemplifies how factor endowments, including not only energy but also technical know-how and real capital, determined how technologies of the industrial revolution and the mineral energy system could be applied in Sweden (Lindqvist, 1984). Already a decade after Newcomen had assembled his first steam engines in England, the powerful Swedish Royal Board of Mining decided to evaluate the technology. The basic challenge that the Board wanted to address was, as in England, flooding of the mines due to hydrological conditions. After the plans on evaluating a steam engine had first surfaced in 1715, just three years after Newcomen's first engine, a so called fire and air machine was built in the Dannemora iron ore mine in 1728, under the auspices of the Swedish engineer Mårten Triewald. Unfortunately, it turned out that the machine consumed excessive quantities of firewood. Since the wood had an alternative use as charcoal for use in the nearby blast furnaces, foundries and forges, the opportunity cost was high. This marks a striking difference to the British case, where the steam engines were set up at the mouth of the coal pit where the fuel cost was close to nothing. In Sweden, however, the costly fuel consumption meant that the machine was not profitable, which in turn deterred the Royal Board of Mining from resolving the remaining technical problems which, among other things, included that it did not operate well under winter conditions. The production factor missing at Dannemora was coal. Know-how, including engineering skills and information on the British developments, was clearly present. The institutional framework was also sufficiently well-functioning for encouraging the investment in the first place but also to scrap the project when profits were not realized ${ }^{2}$.

The first steps towards a transition to a mineral energy system in Sweden came with the Watt steam engine and the British engineer Samuel Owen, a Leeds based engineer who moved to Stockholm in 1804 on initiative from his Swedish business contacts, who had previously bought British steam engines for two breweries, one textile industry and one flour mill (Sundström, 2009). Bob Allen's point that the technologies of the industrial revolution could not be diffused until their designs had been sufficiently refined (Allen, 2009)

2. For those interested, there is a full scale model of the machine on display in Stockholm's Technical Museum. 
therefore seems to be justified also in the Swedish case. In Stockholm, Owen constructed his first steam engines for industrial use, as well as small steamers such as the Witch of Stockholm. Not without reason it is often considered that Owen played an important role in the establishment of a modern engineering industry in Sweden as several spin-offs such as Boliders (nowadays part of Volvo) and Atlas Copco were started by his apprentices. Owen's business operations may, from an organizational perspective, be seen as part of the transition from the biological to the mineral-based energy system in Sweden, and shows on the micro level how individual actors and entrepreneurs played a role in the transition. In essence, Owen, and his Swedish business partners, transferred critical know-how from Britain to Sweden. It is furthermore likely, although it remains a future research issue to fully prove the point, that the fuel demand derived from the increased used of steam engines was a crucial driver behind the early diffusion of the mineral energy system to Sweden.

\section{THE ORIGINS OF THE DEMAND FOR COAL}

As railways directly contributed to an increased demand for coal, the national railway project, with the first trunk line completed in 1856, was one of the main drivers behind the Swedish energy transition. The reason why railways were so important for propelling the transition was that railways did not run well on firewood. The locomotives, originally of British or German designs, were intended to run on coal. As a matter of fact, coal hold much better qualities for steam engines as compared to biofuels such as wood or peat. This is especially so concerning locomotives, with high demands on power and limited size. Here lies some important, but often overlooked technical circumstances which are important to consider. First, coal has a significantly higher energy content in relation to its weight than biofuels. If volume is instead considered, which is some respects is more important than weight, the difference becomes even more striking. One cubic meter of wood is in energy terms equivalent to approximately 0.17 tons of coal. As the density of coal is about twice as that of wood, this means that one cubic meter of coal weighs around two tons, which in energy terms corresponds to around 10 cubic meters of wood. A steam locomotive such as model SJ Litt. B., a Swedish design from 1909, had a fender with a coal storage capacity of 6 tons, corresponding to around 35 cubic meters of wood. Furthermore, as locomotives need to develop significant amounts of power, there is a close relationship between locomotive power and the boiler capacity, measured in tons of steam per hour. One important factor affecting the boiler capacity is the rate at which the fuel can be burned, which gives how much energy that can be transferred to the water in the boiler per hour. Since the area available for burning fuel is limited in a locomotive, attempting to run a locomotive on firewood reduces the boiler capacity and thus the loco- 
motive power by approximately $50 \%$. Coal was also the preferred fuel for stationary industrial steam engines, even though it is possible to keep up the boiler capacity by simply constructing a large boiler and extending the combustion area. Even in this case, a larger boiler would be needed if biofuels were used. Adding to these disadvantages of biofuels, peat and even fire wood also contain some amount of water, which means that energy is spent on drying the fuel itself ${ }^{3}$.

\section{FIGURE 1}

Swedish coal imports by sector of destination, 1800-1913

\subsection{0}

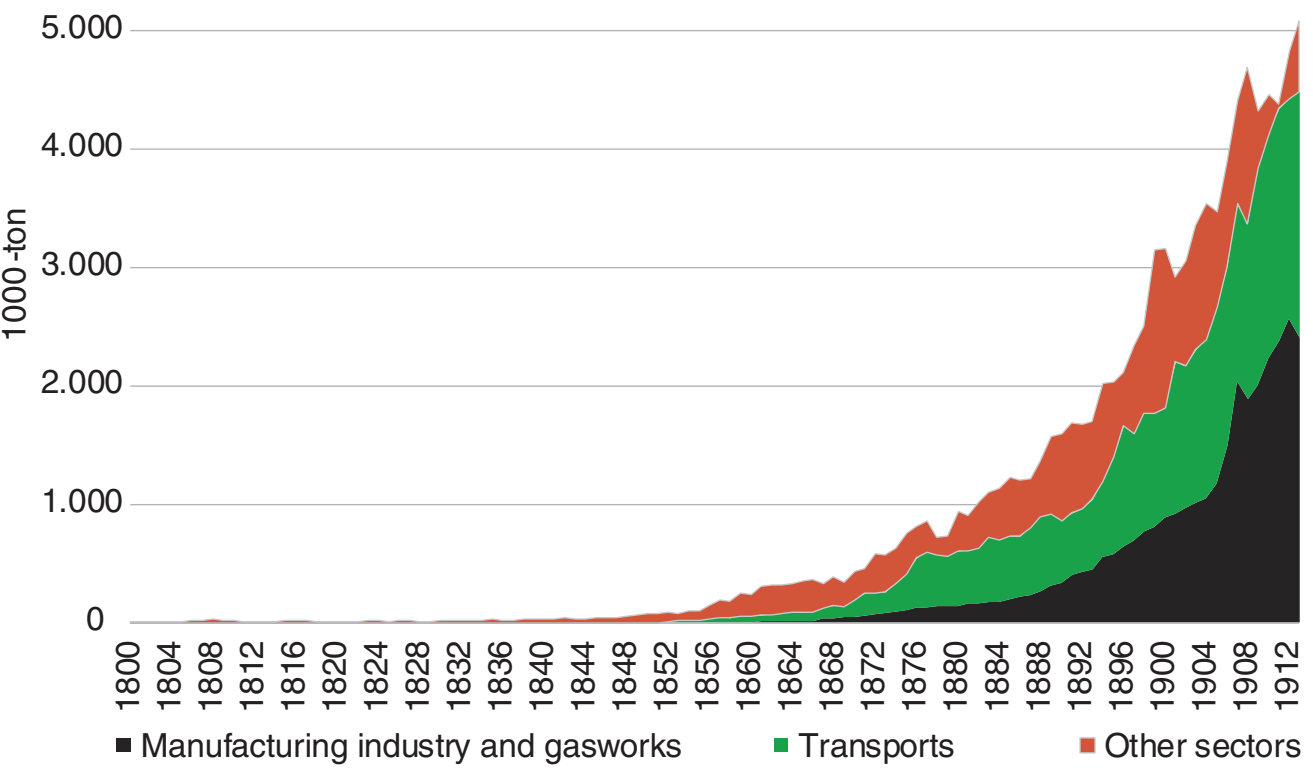

Source: Lindmark and Olsson-Spjut (2018).

In quantitative terms, and as shown in Figure 1, Swedish coal consumption, almost entirely based on imports, began to increase from 1840. Lindmark and Olsson-Spjut have shown that the rise can largely be explained by the increasing steam motive power in the

3. As such, the SJ Litt. B. spent $100-120 \mathrm{~kg}$ of coal for heating one cubic meter of water to a pressure of 12 bar and a temperature of $187 \mathrm{C}$. At top speed $90 \mathrm{~km} / \mathrm{h}$ this amounts to 9 cubic meters and one ton of coal per hour. Under ideal conditions, the SJ Litt. B. could produce 25 tons of steam per hour, which corresponds to three storage high industrial steam engine. (Information based on interview on $16^{\text {th }}$ February 2017 with steam engine expert Michael Carlsson, technical consultant at Solberga Station AB, http://www.solbergastation.se/valkommen.html). 
industry, the development of steamship tonnage, the recorded railway fuel consumption and the coal consumption in gasworks (Lindmark \& Olsson-Spjut, 2018).

Other sectors, including domestic heating and heating of other premises, constituted a smaller, while not insignificant share of the coal consumption in Sweden. Lindmark and Olsson-Spjut (2018) therefore suggested that the increasing demand for coal during the second half of the $19^{\text {th }}$ century was derived from the mechanization of the leading economic sectors during the industrialization. Still, the Swedish energy transition was characterized by a dynamic interaction between the organic energy system and the mineral system, which created synergies between both systems. The expansion of the saw mill industry along the Norrland coast initially utilized mechanical hydropower. Steam power, a technology of the mineral system, grew in importance from the 1850's, especially because steam made it possible to locate the mills to more favorable coastal locations. Still, the saw mill industry could utilize sawdust, a biofuel of the organic energy system, as a main fuel for the steam engines. Such synergies are distinguishing features of the Swedish energy history during the $19^{\text {th }}$ and well into the $20^{\text {th }}$ century. Before we devote further attention to the manufacturing industry we should look at the energy transition from the rural point of view.

\section{FIREWOOD IN THE DOMESTIC SECTOR}

During most of the $19^{\text {th }}$ century, the Swedish primary energy consumption was dominated by fire wood for domestic uses (Kander, 2002). Domestic heating and cooking technologies saw significant improvements during this period, including the tile stoves and, later, the iron stoves, which from the perspective of energy transitions begs the questions whether these heating technologies saved on fire wood to such extent that alternative uses of the forest resources, not the least as basic raw material in the saw mill industry, could be realized. If so, transformations within the organic energy system, may have played an important role in the Swedish industrialization.

The historical sources on household firewood consumption are unfortunately sparse and rather unreliable as far as the $19^{\text {th }}$ century is concerned. We can therefore only make informed guesses about the developments of fire wood consumption prior to the more reliable investigations from the 1920s. What we know is that the bulk of the fuel consumption occurred on the countryside and that the urban fuel consumption, also when counted per capita, was significantly lower due to overcrowding and a more frequent use of tile stoves. Urbanization therefore tended to reduce per capita energy consumption. Both the iron stove and the tile stove were innovations with a higher thermal efficiency 
than traditional fireplaces, but wether the new types of stoves actually reduced per capita firewood consumption in rural areas is not known with certainty. The dilemma is to what degree improved heating efficiency was used for reduced firewood consumption or higher indoor temperatures in combination with an increased number of heated rooms ${ }^{4}$. It is also uncertain how the growth of the landless rural working class in the 1800 's, living in smaller crofts rather than farms, affected the aggregated fuel consumption. If one, as a counterfactual thought experiment, assumes that the domestic per capita firewood consumption was the same in early the $19^{\text {th }}$ century as it was in the 1920 's, one arrives at a consumption around 5 million cubic meters of fire wood in 1800 . This roughly corresponds to the forest industry's consumption of saw timber in the mid-1860s. If, on the other hand, the effects of improved spacing heating technologies were strong, assuming that the per capita consumption halved between 1800 and 1920, the household firewood consumption would have been around 10 million cubic meters in the early $19^{\text {th }}$ century, equivalent to the forest industry's raw material consumption around 1890 (Lundgren, 1984). If so, the energy savings within the household sector would literally have saved significant amounts of firewood.

The forest industry was a key sector in the Swedish industrialization process and the saw mill industry timber consumption rose from one million cubic meters in 1840 to 11 million cubic meters in the 1890s (Lundgren, 1984:223-25). During the same period the total fire wood and charcoal consumption in other manufacturing sectors probably increased from approximately 4.7 million cubic meters to 6.5 million cubic meters of wood (Lindmark \& Olsson-Spjut, 2018). The output growth, measured as the industrial value added volume, increased sevenfold from 30 million to over 225 million 1913 SEK over the same period (Krantz \& Schön, 2007). This demonstrates a sizeable gain in terms of firewood efficiency during the initial phase of Swedish industrialization, which was mainly driven by a more efficient use of charcoal in the iron industry. Coal substituting for firewood or charcoal was hardly important for the developments at the aggregated level during the $19^{\text {th }}$ century as the Swedish iron industry, by far the largest industrial consumer of fuels, largely remained on charcoal until after the First World War.

The vast forest resources in interior northern Sweden were first utilized on commercial scale from approximately 1850. This geographical expansion of the forest industry, known as the timber frontier, originated in the Oslo area in the 1700s. By the 1840's, the frontier had reached the city of Sundsvall and twenty years later northern Västerbotten to, finally, reach Norrbotten by the mid-1870's (Bunte, Gaunitz \& Borgegård, 1982: 135). An important driver was the demand for large, old grown timber which became increas-

4. This problem is discussed in LINDMARK and ANDERSSON (2010: 55-78). 
ingly scarce as the saw mill operations expanded. The timber frontier coincided both with a transformation of the agriculture in interior Norrland and with the development of a distribution system of foodstuffs from southern Sweden to the north and further inland. It is important to recognize that the inland agriculture operated at the geographical edge of farming. The famines of 1867, 1868 and 1869 had demonstrated how sensitive the northern agriculture was to crop failures and how food transports were disrupted when harbours froze over earlier than expected. When analyzing the expansion of logging operations it is important to recognize that the inland agriculture hardly produced any surpluses. Dan Bäcklund stated that the inland Norrbotten farms before 1870 could not even be characterized as subsistence farming, if one, by referring to subsistence farming, means a farm with some surplus production capacity that can be sold in exchange for basic necessities (Bäcklund, 1988). Farming conditions were simply too poor, something that became painstakingly clear during the frequent crop failures, such as the famine in the late 1860s. Bäcklund therefore chose to label this type of agriculture subsistence small farming. Still, this form of agriculture in which grassland farming on outlying, marginal land such as moors, was an essential support for the sparse population. It was the expansion of the sawmill industry along the northern Swedish coast that boosted demand for labor in the hinterland. For instance, Nils-Gustav Lundgren has estimated that the 350,000 cubic meters annually harvested in Jokkmokk area in Norrbotten around the turn of the century required approximately 2,700 forestry workers (Lundgren, 1984). Owing to the high demand for labor, there was also an increased element of wage labor. In the 1880s, about $70 \%$ of smallholders depended on wage income, equivalent to around 200 SEK per year, which in turn was equal to more than 100 days of payments for an agricultural worker (Jörberg, 1972: 714). As forestry expanded and outfield farming was gradually abandoned, it created a structural change within Norrland agriculture. Another outcome was that more male labour in the forest required more women's work in the agriculture (Bäcklund, 1988). In parallel, there were substantial investments in transport networks. Streams were cleared from rocks and other obstructions to allow for timber floating, while timber floatation on the lakes depended on steam tugs (Törnlund, 2002). The road network was expanded from the 1840s as state subsidies were first introduced (Lassila, 1972: 151) and, as Bäcklund notes (1988: 47), the roads were absolutely essential for the expansion of timber cutting from the 1870s. The railway reached Norrbotten in the 1890s and along with coastal steam shipping from the 1840s and the construction of inland roads, this provided the backbone of a distribution system partly organized by forest companies, with the main purpose of providing fodder for horses and food for the lumbers.

Northern Sweden held around 14\% of the Swedish population in 1880, while the output of grain and root vegetables, foremost potatoes, only accounted for $7 \%$ of the country total $(B i S O S, 1880 \mathrm{c})$. The growing population in northern Sweden was therefore de- 
pending on food transports from southern Sweden and from abroad. While the imports of foreign grain to southern and central Sweden constituted less than $7 \%$ of the production of grain in these parts of the country, the corresponding figure for northern Sweden was close to $20 \%$. Of the total Swedish meat imports in 1880, almost $50 \%$ were destined for Norrland (BiSOS, 1880b). These transports were in turn mirroring the industrialization itself. By 1880, the Swedish registered steamer tonnage belonging to staple towns and private owners and intended for domestic trade was half the tonnage of sailing ships (BiSOS, 1880a: tabs. 1, 2, 3). Norrland's share of the sailing ship tonnage was around $7 \%$, while Norrland's share of steamer tonnage was $35 \%$. This is well in line with the hypothesis that modern technology was important for opening previously non-utilized, organic forest resources. The railway reached southern Norrland by the late 1870's and the north, connecting the Swedish trunk line to the Iron ore railway between Luleå and Narvik in 1895. The role of the railways for facilitating the exploitation of the bio-resources of the north is further exemplified by the so-called Norrland Tariff, a railway transport subsidy in effect from 1895 to 1930 and which mainly concerned grain freights from southern to northern Sweden (Pettersson, 1999: 281). The tariff reflected both the southern Swedish farmers need to find new markets, as the foreign competition had become harder during the 1880's, and the fact that Norrland was not self-sufficient in grain and root-vegetables, while at the same time, both the forest industry and the mining industry of the north needed more labour. Thomas Petterson (1999) points out that prior to the railways, factory owners in Norrland were forced to store foodstuffs in the autumn, before the harbors had not yet frozen over, a solution that was both expensive and inconvenient.

The full utilization of the forest therefore depended on Sweden's integration into the world economy and the use of coal based transportation systems. In short, while sawn timber wasexported to the European markets, food from southern Sweden and abroad such as American pork was distributed to the hinterland. The role of coal was indirect as a fuel in both the transportation networks and in the engineering industry that delivered machines to the saw mills.

\section{THE CHARCOAL CONSUMPTION IN THE IRON WORKS}

As previously pointed out, the charcoal consumption of the ironworks was significant. Estimates suggest that 21 million hectoliters of charcoal was consumed around the year 1800 , equivalent to approximately 2.5 million cubic meters of wood, which meant that the ironworks required a hinterland for the supply of fuel and foodstuffs for the labor force. The localization pattern of the ironworks was therefore rather diffused (Olsson, 2007). This was not only a reflection of the area dependence of the organic energy system, but 
also due to the difficulties in transporting charcoal long distances without the charcoal shaking down into a powder. The production of charcoal was also strictly regulated, which should be kept in mind when the role of relative prices in the energy transformation is analyzed. To start with, there was a pre-emption obligation within the mining district (Olsson, 2007: 43). A Yeoman was obliged to first offer the charcoal to the local iron work to a useful price. Only if they turned down the offer, it was allowed to sell charcoal outside the mining district Bergslagen. This regulation was abolished in 1850. The charcoal market outside Bergslagen was liberated in 1846, motivated by the elimination of the Forging Ordinance the same year (Olsson, 2007). This means that market prices for charcoal only came to existence from 1850 .

The localization of ironworks, huts and hammers was administered by the crown, through the Swedish Board of Mines, which set productions allowances and conceded privileges for different parts of the iron production process. This was both an expression of the mercantilist state and of resource management of limited forest and hydropower assets (Olsson, 2007: 39-42). By the second half of the $19^{\text {th }}$ century, the iron industry was in a process of rationalization with extensive closures. At the same time, however, iron production increased, implying a concentration to larger units (Attman, 1986). The transformation pressure was due in turn to the lower iron prices due to the increased supply of British iron, which in turn ultimately depended on the increased production capacity and high productivity achieved through coke-fired blast furnaces, in short England's transition to a mineral based energy system. The transformation of the organic economy in Sweden could, theoretically, be the expected result if the price of coal fell relative to fire wood and charcoal. It is, however, important to realize that saw timber did not have an alternative use as firewood or charcoal since the saw mill industry used larger timber dimensions as compared to the dimensions used for fuels. First, large dimension timbers, often around 90 centimeters in diameter, were not as prone to sinking as smaller dimensions when floated. Second, debarking a big log was more labor efficient per cubic meter as compared to debarking a smaller log. In both cases this is due to the geometrics of the cylinder; how surface area, which rises to the power of two, is related to volume, which rises to the power of three. Thirdly, the saw dust waste was relatively smaller when sawing larger logs. It is more convenient to handle and split smaller logs, thus explaining why these dimensions were used for charcoal and firewood. Since large and small timber were not close substitutes, it is important to collect prices for both sawtimber and firewood. The fuel and timber prices are shown in Figure 2. 
FIGURE 2

Fuels and wood prices per MJ relative to coal. Sweden, 1866-1910

3

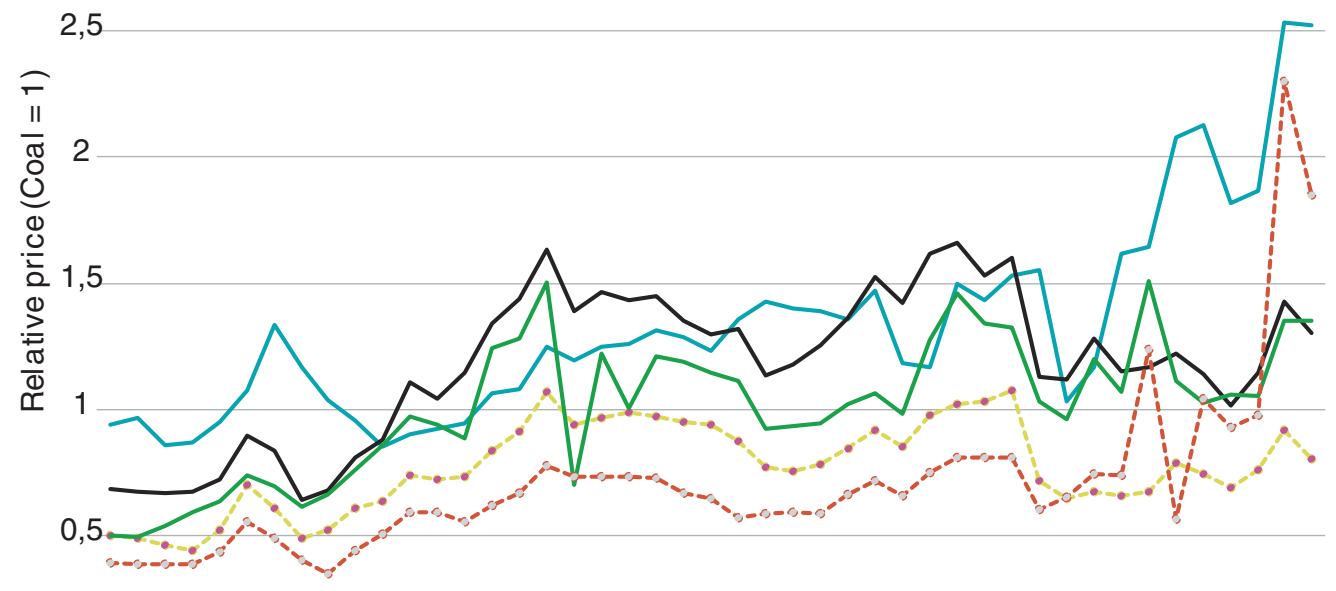

0

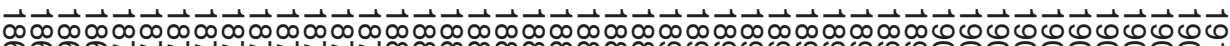

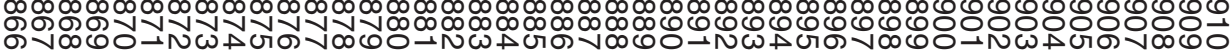

- Birch-to-coal — Sawtimber-to-coal -s-Pulp wood-to-coal

- Charcoal-to-coal -•-Pine-to-coal

Sources: coal (Statens Järnvägar; BiSOS, 1866-1902; Kander, 2002: 1903-1910); charcoal (Olsson, 2007; based on Jörberg, 1972); wood pine (Jörberg, 1972); wood birch (Jörberg, 1972: 498ff, Skaraborg County); pulp wood (Ljungberg, 1990).

There is no reliable information on the development of coal prices in Sweden from mid1860, while a compilation coal prices for earlier dates have not been made. The prices published as Swedish prices are, as shown by Fredrik Olsson indeed series from the Danish historical national accounts, which in turn were transformations of British export prices (Olsson 2007: 50-51). The prices from 1866 have been collected from the State Railways (Lindmark \& Olsson-Spjut, 2018). Charcoal prices were approximately 5 to $15 \%$ lower per Joule than coal prices until 1880, when charcoal became approximately $20 \%$ more expensive than coal. This price relation lasted throughout the 1880's and early 1890 's. This means that if coal and charcoal had been perfect substitutes, coal ought to have replaced charcoal in the iron industry no later than 1880 . Since that was not the case, the two fuels cannot have been perfect substitutes. Also, relative prices were relatively stable. A more pronounced relative price shift did only occur during the period from 1894 and onwards. By the year 1900 charcoal was $50 \%$ more expensive than coal, and by 1910 charcoal was 
three times as expensive. There were two reason for this. First, technical change had given rise to an alternative use of spill wood and small timber dimensions as pulpwood. When demand for small-sized timber increased, prices rose, which in turn drew up the charcoal prices. Secondly, industrialization itself caused an increased demand for labor, which caused rising wages also for the coalers. Charcoal production was relatively labor intensive, which shifted the cost structure especially for charcoal. The combination of the expansion of the pulp and paper industry from especially the 1890s and more rapidly increasing wages from the same decade explain the late switch from charcoal to coke in Swedish blast furnaces, where the first coke fired furnace was started in 1905. In short, it seems as if the major price-wise reason to switch to coke happened when increased demand for small wood also made charcoal more expensive. Simultaneously with the changeover to coke, there was also an increased tendency of concentration in the iron industry into fewer but larger units. This processes came to a climax during the economic crisis of the early 1920's crisis, which virtually wiped out charcoal fired blast furnaces (Söderlund \&Wretblad, 1957). The bottom-line is that coke enabled increased economies of scale in the iron industry. The late transition to coke in Swedish iron manufacturing may in turn be explained by the development of relative prices for coal, firewood and labour. These changes were in turn partly the result of the dynamics between the organic and mineral energy systems, as it was the evolution of a wood based pulp and paper industry that propelled the final stages of the transformation of the iron industry from charcoal to coke. First, the pulp and paper industry's demand for small timber resulted in rising prices for these dimensions which altered the relative prices between coal and coke and, thereby, the cost structure in the iron industry. At first only spruce was used for paper pulp production, but as pine also became available for the pulp manufacturing process, the competition over timber hardened between the paper pulp industry and the charcoal manufacturing. Secondly, and as noticed previously, the slender timber dimensions were inclined to sinking if floatation was attempted. The forest industry's cleansing of natural streams for more efficient timber floatation, investments in coal consuming steamers, tugs and railways, made it possible to secure supplies of raw materials to the pulp industry around the turn of the century. Finally, while the raw material used in the pulp manufacturing process was organic, the pulp and paper mills were highly depending on coal. In 1913, the first year for which reliable data on the sectoral coal consumption in Sweden exists, the pulp and paper industry accounted for around $30 \%$ of the manufacturing industry's total coal consumption. Coal fired steam engines were not the least used for driving generators, providing electricity for machines. It is therefore not surprising to learn that the pulp and paper industry's share of the total installed engine power of the Swedish manufacturing industry was also around 30\% in 1913. The pulp and paper industry also changed forestry itself as smaller timber dimensions became more valuable (Heckscher, 1941). First, thinning of the forests became profitable, thereby improving the 
growth rate of large trees intended for saw timber. Secondly, a shorter turn-around time meant that less capital was sunk in growing forests. This improved the profitability of forest companies and probably facilitated the emergence of sustainable forestry and practices that stood in sharp contrast to the $19^{\text {th }}$ century forest tycoons, often associated with illegal logging, land grabbing, unethical business methods and deforestation (Gaunitz, 1990).

At this stage we are inclined to draw some tentative conclusions if we first can explain why the use of coal increased dramatically, in presence of an absolute price disadvantage in terms of cost per energy unit over firewood, while there were no dramatic changes in relative prices between biofuels (firewood and charcoal) and coal until the turn of the century. Price data shows that coal was at all occasions more expensive than pine wood, while slightly less expensive than birch wood.

The difference in price level can be explained if coal and charcoal were not perfect substitutes in every respect. As previously argued this was clearly the case concerning steam engines and especially so steam engines requiring a high boiler capacity, such as locomotives. Thus, we can conclude that the increased demand for coal was primarily derived from the demand for mechanical power provided by steam engines in the manufacturing industry and transport sectors. This explains why the coal consumption increased despite coal being more expensive than pine firewood in terms of energy and despite the fact that coal prices in comparison to biofuels remained fairly stable. In order to explain why the relative prices were stable we need to conclude that coal and firewood were close substitutes in low-end uses, such as residential heating. Coal had an edge over firewood, but only in cities with houses equipped with central heating and major coal imports for industrial uses and gas works (Lindmark \& Andersson, 2010). Firewood therefore remained an important domestic fuel well after the period studied here.

\section{HYDROPOWER}

Hydropower was an important organic energy source which also was part of the dynamics between the organic and mineral energy systems. This transformation rested on two basic innovations, the turbine and alternating current technologies. The first wave of saw mill expansion was based on mechanical hydropower using water wheels. During the early stages of Swedish industrialization, mechanical hydropower was essential for both the expanding saw mill industry and had since long been of great strategical importance for the iron industry. Gösta Eriksson even suggested that the demand for additional hydropower contributed to the spatial diffusion of the iron industry during the $19^{\text {th }}$ century (Eriks- 
son, 1955). Indeed the total effect of mechanical hydropower in the manufacturing industry and mining was larger than that of steam power as late as 1900 (BiSOS, 1900a, 1900b). The official statistics reports approximately 250,000 HP in mechanical hydropower and 174,000 HP in steam engines. Hydropower therefore substituted for coal during the Swedish industrialization, even if it is difficult to estimate the importance in terms of energy flows, as mechanical hydropower usually did not admit continuous operation throughout the year. The first turbines came to Sweden from Switzerland and France in the early 1840s's and domestic production commenced a few years later with flour and saw mills as the main customers (Spade, 2008: 35-6). From 1893 hydropower was again transformed through the emergence of electrical engineering and alternating current technologies. This time Sweden jumped on the bandwagon as one of the leading nations. At the turn of the century, around $13 \%$ of the mechanical water power was used for driving generators (BiSOS, 1900b). The considerable difference between industries regarding the use of hydropowered generators is an indicator of the structural transformation of the second industrial revolution. The new industries that represented the $20^{\text {th }}$ century economy were often based on the use of electricity. More than $90 \%$ of the mechanical hydropower in the chemical industry was used for driving generators. And concerning electrical generators, the chemical industry was dominated by chlorate and calcium carbide manufacturing. Chlorate was used in the match and explosives industries, both emerging industries. Calcium carbide was used in the manufacturing of acetylene gas, which in turn was used in carbide lamps, as a welding gas and for purifying steel from sulfur. The transformation of hydropower from mechanical to electrical hydropower was therefore also part of a co-evolutionary process between the organic and mineral energy systems.

\section{CONCLUSIONS}

The Swedish industrialization was characterized by the co-evolution of the organic and mineral energy systems. The saw mill industry was depending on the establishment of transportation systems bringing in food stuffs for laborers and loggers in the north and for transporting timber and sawn products to the coast and foreign markets. Thus, the raw materials utilized were products of the organic energy system, while the transport system was a mix of technologies of the organic system, such as sailing ships and streaming rivers, and technologies of the mineral system, including steamers, tugs and railways. The diffusion of the mineral energy system was strongly associated with the mechanization of the manufacturing industry and transports sectors where firewood and coal were not as close substitutes as one could imagine. We therefore propose that demand for coal was mainly derived from the demand for steam powered machines while pure substitution effects, coal 
substituting for firewood, were less important during the $19^{\text {th }}$ century. The evolution of the wood based pulp and paper industry during the late $19^{\text {th }}$ century exemplifies the dynamics of the co-evolution of the organic and mineral energy systems. As the pulp industry increased the demand for small timber, prices rose for these dimensions which made firewood and charcoal more expensive relative to other fuels. This contributed to the shift from charcoal to coke in the iron industry but also changed the economic situation in forestry as forest management became more profitable. Finally, also hydropower was part of the change. Mechanical hydropower had been an important factor of production with regard to the iron industry and, from the mid- $19^{\text {th }}$ century, the saw mill industry. With the emergence of electricity, hydropower came to form the center of new clusters of industry and innovation for the $20^{\text {th }}$ century. The Swedish example demonstrates how the dynamics of energy transitions unfold in several dimensions, geographical, technological, economical, entrepreneurial and institutional, and that these dimensions are often interconnected. It is important to consider that aggregated analyses, focusing on easily quantified dimensions such as the composition of energy carriers, total energy growth and relative prices, may obscure how energy transformations are linked to the general economic history of specific countries.

\section{ACKNOWLEDGEMENTS}

The authors would like to thank the anonymous reviewers for their valuable comments and suggestions to improve the quality of the paper. The research was supported by Stiftelsen Riksbankens Jubileumsfond through the project "The limits to growth in a sustainable society: Energy use and area requirements in early modern Sweden" (Dnr P100701:1) and Jan Wallanders och Tom Hedelius Stiftelse samt Tore Browaldhs Stiftelse "Engines for sustainability. Horsepower prices, capital sub- stitution and energy transitions in the long run".

\section{REFERENCES}

Allen, R. C. (2009). The British Industrial Revolution in Global Perspective. Cambridge: Cambridge University Press.

ATtMan, A. (1986). Svenskt järn och stål 1800-1914. Stockholm: Jernkontoret. (Jernkontorets bergshistoriska skriftserie, 21).

BäCKLUND, D. (1988). I industrisamhällets utkant: Småbrukens omvandling i Lappmarken 1870-1970. Doctoral dissertation. Umeå: Umeå Universitet.

BiSOS (1866-1902). Statens järnvägar (L). Stockholm: Statistics Sweden. 
Bunte, R., GAUnITZ, S. \& BorgegÅRD, L. E. (1982). Vindeln: En norrländsk kommuns ekonomiska utveckling 1800-1980: En analys av bondesamhällets ekonomiska utveckling, anpassning och förvandling under 200 år. Lund: Degerfors.

ERIKssON, G. A. (1955). Bruksdöden i Bergslagen efter 1850: Med särskild hänsyn till företag $i$ Kolbäcksåns dalgång. Stockholm: Jernkontoret. (Jernkontorets Bergshistoriska Skriftserie, 15).

GADD, C. J. (2000). Det svenska jordbrukets historia. 3: Den agrara revolutionen 17001870. Stockholm: Natur och Kultur.

Gales, B., Kander, A., Malanima, P. \& Rubio, M. (2007). North versus South: Energy Transition and Energy Intensity in Europe over 200 Years. European Review of Economic History, 11(2), 219-253.

GAUNITZ, S. (1980). Baggböleriet-om konsten att avverka norrlandsskogarna utan att bryta för mycket mot lagen. Västerbotten, (1), 2-14. http://staging.vbm.se/wp-content/uploads/2017/09/1980_1.pdf

HARRISON, D. (2002). Farlens sekel: En berättelse om 1200-talets Sverige. Stockholm: Ordfront.

HeCKSCHER, E. F. (1941). Svenskt arbete och liv: Från medeltiden till nutid. Stockholm: Bonnier.

Jonsson, K. (2001). Färnhanteringen i norra Västergötland:Arkeologiska undersökningar i Essunga, Främmestad, Istrum, Ledsjö, Lerdala, Vättlösa och Älgerås socknar. Stockholm: Jernkontoret. (Jernkontorets Bergshistoriska Utskott, 71).

Jörberg, L. (1972). A History of Prices in Sweden 1732-1914. 1: Sources, Methods, Tables. Lund: Gleerup.

KANDER, A. (2002). Economic Growth, Energy Consumption and CO2 Emissions in Sweden 1800-2000. Doctoral dissertation. Stockholm: Almqvist \& Wiksell. (Lund Studies in Economic History, 19).

Kander, A., Malanima, P. \& Warde, P. (2013). Power to the People: Energy in Europe over the Last Five Centuries. Princeton: Princeton University Press.

KRANTZ, O. \& SCHÖN, L. (2007). Swedish Historical National Accounts 1800-2000. Stockholm: Almqvist \& Wiksell. (Lund Studies in Economic History, 41).

LASSILA, M. (1972). Vägarna inomVästerbottens län: Kommunikationernas utveckling mot bakgrund av befolkning och näringsliv. Umeå: Umeå Universitet.

LindMARK, M. \& ANDERSSON, L. F. (2010). Household Firewood Consumption in Sweden during the Nineteenth Century. Fournal of Northern Studies, (2), 55-78.

LINDMARK, M. \& Olsson-SpJuT, F. (2018). From Organic to Fossil and In-Between: New Estimates of Energy Consumption in the Swedish Manufacturing Industry during 1800-1913. Scandinavian Economic History Review, 66 (1), 18-33. 
LindMARK, M. \& MindE, K. B. (2018) Et energiregnskap for Fastlands-Norge 18352012/Energy Consumption in the Norwegian Mainland Economy 1835-2012. Heimen, 55 (2), 157-177.

LINDQvist, S. (1984). Technology on Trial: The Introduction of Steam Power Technology into Sweden, 1715-1736. Uppsala/Stockholm: Uppsala Universitet/Alqvist \& Wiksell. (Uppsala studies in history of science, 1 ).

Linnaeus, C. (1960 [1732]). Carl von Linnés lappländska resa: Caroli Linnci Iter Lapponicum. Stockholm: Natur och Kultur.

LJungBeRG, J. (1990). Priser och marknadskrafter i Sverige 1885-1969: En prishistorisk studie. Doctoral thesis. Lund: Ekonomisk-historiska fören. (Skrifter utgivna av Ekonomisk-historiska föreningen, 64).

LUNDGREN, N. G. (1984). Skog för export: Skogsarbete, teknik och försörjning $i$ Lule älvdal 1870-1970. Doctoral dissertation. Umeå: Umeå Universitet. (Umeå studies in Economic History, 6).

Myrdal, J. (Ed.) (1999). Det svenska jordbrukets historia. 2: Fordbruket under feodalismen: 1000-1700. Stockholm: Natur och kultur.

Norberg, P. (1958). Forna tiders järnbruk $i$ Norr- och Västerbotten. Stockholm: Almqvist \&Wiksell.

Olsson, F. (2007). Färnhanteringens dynamik: Produktion, lokalisering och agglomerationer i Bergslagen och Mellansverige 1368-1910. Doctoral dissertation. Umeå: Umeå Universitet. (Umeå studies in Economic History, 35).

Pettersson, T. (1999). Institutional Rigidity and Economic Change: A Comparison between Swedish Transport Subsidies. In L. ANDERSSON-SKog \& O. KRANTZ (Eds.), Institutions in the Transport and Communications Industries: State and Private Actors in the Making of Institutional Patterns, 1850-1999 (pp. 199-215). Canton: Science History Publications.

Pomeranz, K. (2000). The Great Divergence: China, Europe, and the Making of the Modern World Economy. Princeton: Princeton University Press.

SIEFERLE, R. P. (2001). The Subterranean Forest: Energy Systems and the Industrial Revolution. Cambridge: The White Horse Press,

Söderlund, E. \& WretBlad, P. E. (1957). Fagerstabrukens historia. 3: Nittonhundratalet. Uppsala: Almqvist \& Wiksell.

SörLIN, S. (1988). Framtidslandet: Debatten om Norrland och naturresurserna under det industriella genombrottet. Stockholm: Carlssons.

SPADE, B. (2008). En historia om kraftmaskiner. Stockholm: Riksantikvarieämbetet.

SundSTRÖM, A. (2009). Samuel Owen:Teknik- och ångbåtspionjär. In Deedalus:Tekniska museets årsbok. Vol. 77. Stockholm: Tekniska museet.

SVerige Kommerskollegium (1880a). Bidrag till Sveriges officiella statistik (BiSOS). E) Inrikes och sjöfart handel. Stockholm: L. J. Hjerta. 
SVerige KommersKollegium (1880b). Bidrag till Sveriges officiella statistik (BiSOS).

F) Utrikes handel och sjöfart. Stockholm: L. J. Hjerta.

SVerige Kommerskollegium (1880c). Bidrag till Sveriges officiella statistik (BiSOS).

N) Fordbruk och boskapsskötsel. Stockholm: L. J. Hjerta.

SVerige KommersKollegium (1900a). Bidrag till Sveriges officiella statistik (BiSOS).

C) Bergshandteringen. Stockholm: L. J. Hjerta.

SVerige KommersKollegium (1900b). Bidrag till Sveriges officiella statistik (BiSOS).

D) Fabriker och handtverk. Stockholm: L. J. Hjerta.

TÖRNLUND, E. (2002). "Flottningen dör aldrig”: Bäckflottningens avveckling efter UmeochVindelälven 1945-70. Doctoral dissertation. Umeå: Umeå Universitet. (Studies in Economic History, 27).

Wilkinson, R. G. (1988). The English Industrial Revolution. In D. WorsteR (Ed.), The Ends of the Earth: Perspectives on Modern Environmental History. Cambridge: Cambridge University Press.

Wrigley, E. A. (1962). The Supply of Raw Materials in the Industrial Revolution. The Economic History Review, 15 (1), 1-16.

Wrigley, E. A. (1988). Continuity, Chance and Change: The Character of the Industrial Revolution in England. Cambridge: Cambridge University Press.

Wrigley, E. A. (2010). Energy and the English Industrial Revolution. Cambridge: Cambridge University Press.

WrIgley, E. A. (2016). The Path to Sustained Growth: England's Transition from an Organic Economy to an Industrial Revolution. Cambridge: Cambridge University Press. 